\title{
Selective Catalytic Oxidation (SCO) of Ammonia to Nitrogen over Hydrotalcite Originated Mg-Cu-Fe Mixed Metal Oxides
}

\author{
Lucjan Chmielarz • Agnieszka Węgrzyn • \\ Magdalena Wojciechowska • Stefan Witkowski • \\ Marek Michalik
}

Received: 22 February 2011/ Accepted: 20 June 2011 / Published online: 2 July 2011

(C) The Author(s) 2011. This article is published with open access at Springerlink.com

\begin{abstract}
Mg}-\mathrm{Cu}-\mathrm{Fe}$ oxide systems, obtained from hydrotalcite-like precursors, were tested as catalysts for the selective catalytic oxidation (SCO) of ammonia. Copper containing catalysts were active in low-temperature SCO processes; however, their selectivity to nitrogen significantly decreased at higher temperatures. The optimum composition of the catalyst to guarantee high activity and selectivity to $\mathrm{N}_{2}$ was proposed. Temperature-programmed experiments, SCO catalytic tests performed with various contact times and additional tests on the samples in the selective catalytic reduction of NO with ammonia showed that the SCO process over the studied calcined hydrotalcites proceeds according to the internal SCR mechanism and oxidation of ammonia to NO is a rate-determining step in the low-temperature range.
\end{abstract}

Keywords Hydrotalcite-like materials - Selective catalytic oxidation of ammonia $\cdot$ Reaction mechanism

\section{Introduction}

The increasing problem of atmospheric pollution by various $\mathrm{N}$-containing compounds, such as $\mathrm{NO}, \mathrm{N}_{2} \mathrm{O}, \mathrm{NO}_{2}$, and $\mathrm{NH}_{3}$, has resulted in stricter regulations on their emissions. Many chemical processes have ammonia as a reactant or

L. Chmielarz $(\bowtie) \cdot$ A. Węgrzyn · M. Wojciechowska ·

S. Witkowski

Faculty of Chemistry, Jagiellonian University, Ingardena 3,

30-060 Kraków, Poland

e-mail: chmielar@chemia.uj.edu.pl

M. Michalik

Institute of Geological Sciences, Jagiellonian University,

Oleandry 2a, 30-063 Kraków, Poland produce ammonia as a by-product (e.g., nitric acid and nitrogen fertilizer production, urea manufacturing, hydrodenitrification process, DeNOx process). The selective catalytic oxidation ( $\mathrm{SCO}$ ) of ammonia by oxygen to nitrogen and water vapour, according to the reaction given below, is one of the most promising methods for the removal of $\mathrm{NH}_{3}$ from oxygen containing waste gases.

$4 \mathrm{NH}_{3}+3 \mathrm{O}_{2}=2 \mathrm{~N}_{2}+6 \mathrm{H}_{2} \mathrm{O}$

$\mathrm{N}_{2} \mathrm{O}$ and $\mathrm{NO}$ are the main by-products of this process. Therefore, the effective SCO catalysts should operate at a relatively low-temperature range and additionally should result in the production of nitrogen and water vapour.

Various transition metal oxides including $\mathrm{CuO}, \mathrm{Fe}_{2} \mathrm{O}_{3}$, $\mathrm{Co}_{3} \mathrm{O}_{4}, \mathrm{MnO}_{2} \mathrm{MoO}_{3}, \mathrm{~V}_{2} \mathrm{O}_{5}$ (e.g., [1-6]) were tested as catalysts for the $\mathrm{SCO}$ process. Among them the catalysts containing copper and/or iron were found to be some of the most interesting systems.

Recently, there have been a number of published studies on the use of $\mathrm{Cu}$-containing catalysts for the SCO process. Copper oxide deposited on alumina, titania, and zeolites exchanged with copper were found to be active and selective catalysts for the low-temperature SCO process, however, their catalytic performance was significantly decreased by the presence of water vapour in the reaction mixture [7-10]. Hung [11] has shown high activity of a $\mathrm{CuO} / \mathrm{La}_{2} \mathrm{O}_{3}$ oxide system obtained by the co-precipitation method, while Cui et al. [6] reported high activity and selectivity to nitrogen of the mesoporous $\mathrm{CuO} / \mathrm{RuO}_{2}$ catalysts obtained by a co-nano casting-replication method. On the other hand, saponite intercalated with silica pillars and modified with copper and iron were found to be active and selective catalysts for selective ammonia oxidation [12]. However, the $\mathrm{Cu}$-modified clays were active at lower temperatures than the samples doped with iron. 
Our previous studies have shown that hydrotalcite-like materials are very interesting precursors of the catalysts for the SCO process [13]. Hydrotalcites, also called layered double hydroxides (LDHs), show the brucite-like network $\left[\mathrm{Mg}(\mathrm{OH})_{2}\right]$, where the octahedra of $\mathrm{Mg}^{2+}$, six-coordinated to $\mathrm{OH}^{-}$, form parallel layers. Some of the $\mathrm{Mg}^{2+}$ cations are replaced by trivalent ones (e.g., $\mathrm{Al}^{3+}$ ) which result in an increase of the positive charge density of the layer. This net positive charge is compensated by anions (e.g., $\mathrm{CO}_{3}{ }^{2-}$, $\mathrm{NO}_{3}{ }^{-}$) which together with water molecules are located in the interlayer space. Furthermore, some of the $\mathrm{Mg}^{2+}$ as well as $\mathrm{Al}^{3+}$ ions can be replaced, respectively, by other di(e.g., $\mathrm{Cu}^{2+}$ ) and/or tri-valent (e.g., $\mathrm{Fe}^{3+}$ ) cations. Calcination of the hydrotalcite precursors results in their decomposition and the formation of thermally stable mixed metal oxides characterized by a relatively high surface area and homogenous distribution of metal cations. Taking into account the properties mentioned above and additionally a large number of various metals, which can be incorporated into brucite-like layers, hydrotalcites are very promising materials for possible applications in catalysis. Our previous studies [13-15] have shown that catalysts obtained from $\mathrm{Cu}-\mathrm{Mg}-\mathrm{Al}$ hydrotalcites were active in the lowtemperature range, but their selectivity to $\mathrm{N}_{2}$ drastically decreased with an increase in the reaction temperature. On the other hand calcined $\mathrm{Mg}-\mathrm{Fe}-\mathrm{Al}$ hydrotalcite was less active but presented much higher selectivity to nitrogen. Therefore, a series of $\mathrm{Cu}-\mathrm{Mg}-\mathrm{Fe}$ hydrotalcite-like materials with the various ratio of $\mathrm{Cu} / \mathrm{Fe}$ were synthesized and tested as catalysts for the SCO process. Another goal of the studies was the recognition of the reaction mechanism over the hydrotalcite derived catalysts.

\section{Experimental}

\subsection{Catalysts Preparation}

A series of $\mathrm{Mg}(\mathrm{II}) \mathrm{Cu}(\mathrm{II}) \mathrm{Fe}(\mathrm{III})$ hydrotalcite-like materials was prepared by the co-precipitation method using aqueous solutions of the following metal nitrates: $\mathrm{Mg}\left(\mathrm{NO}_{3}\right)_{2} \cdot 6 \mathrm{H}_{2} \mathrm{O}$ (Sigma), $\mathrm{Cu}\left(\mathrm{NO}_{3}\right)_{2} \cdot 3 \mathrm{H}_{2} \mathrm{O}$ (Merck) and $\mathrm{Fe}\left(\mathrm{NO}_{3}\right)_{3} \cdot 9 \mathrm{H}_{2} \mathrm{O}$ (POCh). A solution of $\mathrm{NaOH}$ (POCh) was used as a precipitating agent. The mixture of metal nitrate solutions was slowly added to a vigorously stirred aqueous solution containing a slight excess of $\mathrm{Na}_{2} \mathrm{CO}_{3}$ (POCh). The $\mathrm{pH}$ was maintained constant at $11.0 \pm 0.2$ by dropwise addition of $\mathrm{NaOH}$ solution. Precipitates were aged in a suspension at $60{ }^{\circ} \mathrm{C}$ for $30 \mathrm{~min}$ under vigorous stirring. In the next step the suspension was filtered, washed with distilled water and dried overnight at $100{ }^{\circ} \mathrm{C}$. Finally, the prepared hydrotalcite-like materials were calcined at $600{ }^{\circ} \mathrm{C}$ for $12 \mathrm{~h}$ in an air atmosphere. The catalysts with the $\mathrm{Mg}: \mathrm{Cu}: \mathrm{Fe}$ molar ratios of $2: 1: 1,2: 0.75: 1,2: 0.5: 1,2: 0.25: 1$, and $2: 0: 1$ were prepared. The samples were kept in a desiccator in order to avoid the reconstruction of the hydroxide structure.

\subsection{Catalysts Characterization}

The X-ray diffraction (XRD) patterns of as-synthesized and calcined hydrotalcite-like materials were recorded with a Philips X'Pert APD diffractometer using $\mathrm{CuK}_{\alpha}$ radiation $(\lambda=1.54056 \AA)$.

The surface areas of the calcined hydrotalcites were determined by the BET method using a Quantasorb Junior sorptometer (Ankersmit). Prior to nitrogen adsorption at $-196{ }^{\circ} \mathrm{C}$ the samples were outgassed in a nitrogen atmosphere at $250{ }^{\circ} \mathrm{C}$ for $2 \mathrm{~h}$.

The TPRed (temperature-programmed reduction) of the samples (30 mg) was carried out from room temperature to $1,100{ }^{\circ} \mathrm{C}$ with a linear heating rate of $5{ }^{\circ} \mathrm{C} / \mathrm{min}$. Measurements were performed in a fixed-bed flow micro reactor (i.d., $4.0 \mathrm{~mm}$; bed height, $3 \mathrm{~mm}$ ). Prior to the TPRed experiment, the samples were calcined at $600{ }^{\circ} \mathrm{C}$ for $12 \mathrm{~h}$. The TPRed runs were carried out in a flow of 10 vol\% of $\mathrm{H}_{2}$ diluted in $\mathrm{Ar}$ (Messer) with a total flow rate of gas mixture of $6 \mathrm{~mL} / \mathrm{min}$. Evolving water was removed from effluent gas by means of a cold trap. The evolution of hydrogen was detected by micro volume TCD (Valco).

\subsection{Catalytic Tests}

The catalytic performance of calcined hydrotalcites in the selective catalytic oxidation of ammonia ( $\mathrm{SCO}$ ) has been studied under atmospheric pressure in a fixed-bed flow reactor (i.d., $7 \mathrm{~mm}$; L, $240 \mathrm{~mm}$ ). The reactant concentrations were continuously measured using a quadruple mass spectrometer (VG QUARTZ) connected to the reactor via a heated line. Prior to the reaction, each sample of the catalyst (100 mg) was outgassed in a flow of pure helium at $600{ }^{\circ} \mathrm{C}$ for $1 \mathrm{~h}$. The composition of the gas mixture at the reactor inlet was $\left[\mathrm{NH}_{3}\right]=0.5 \mathrm{vol} \%,\left[\mathrm{O}_{2}\right]=2.5 \mathrm{vol} \%$ and optionally $\left[\mathrm{H}_{2} \mathrm{O}\right]=3.4$ vol\%. Helium (grade 5) was used as balance gas. The total flow rate of the reaction mixture was $40 \mathrm{~mL} / \mathrm{min}$, while the space velocity was about $15,400 \mathrm{~h}^{-1}$. Water vapour was introduced by passing the helium flow through a water saturator at elevated temperature. The reaction was studied at temperatures ranging from 50 to $450{ }^{\circ} \mathrm{C}$. The intensities of the mass lines corresponding to all reactants and possible products were measured at a given temperature for at least $30 \mathrm{~min}$ after the reaction had reached a steady-state. The signal of the helium line served as the internal standard to compensate small fluctuations of the operating pressure. The sensitivity factors of analyzed lines were calibrated using commercial mixtures of gases. The possible changes in the molar flow 
caused by $\mathrm{NH}_{3}$ conversion were negligible in the diluted reaction mixtures. The differences between the reactor inlet and outlet molar flows of the reactants were used to determine conversion of the reactants.

Apart from the studies of the SCO process, calcined hydrotalcites were tested in the role of catalyst for the process of selective catalytic reduction of NO (NO-SCR). The catalytic experiments were performed in a fixed-bed flow reactor system, which was described above. The reactant concentrations were continuously measured using a quadruple mass spectrometer (VG QUARTZ) connected directly to the reactor outlet. Prior to the reaction, each sample $(100 \mathrm{mg})$ of the catalyst was outgassed in a flow of pure helium at $600{ }^{\circ} \mathrm{C}$ for $30 \mathrm{~min}$. The following composition of the gas mixture was used: $[\mathrm{NO}]=\left[\mathrm{NH}_{3}\right]=$ $0.25 \mathrm{vol} \%,\left[\mathrm{O}_{2}\right]=2.5 \mathrm{vol} \%$. Helium was used as a balancing gas at a total flow rate of $40 \mathrm{~mL} / \mathrm{min}$.

\subsection{Studies on the Reaction Mechanism}

\subsubsection{Temperature-Programmed Desorption $\left(\mathrm{NH}_{3}-\mathrm{TPD}\right)$ and Temperature-Programmed Surface Reaction $\left(\mathrm{NH}_{3}-\mathrm{TPSR}\right)$}

The interaction of the catalysts with ammonia was studied by temperature-programmed desorption of ammonia $\left(\mathrm{NH}_{3}-\mathrm{TPD}\right)$ and temperature-programmed surface reaction ( $\mathrm{NH}_{3}$-TPSR). The measurements were performed in a flow micro reactor system equipped with a QMS detector (VG Quartz). Prior to the ammonia sorption the sample $(100 \mathrm{mg})$ was outgassed in a flow of pure helium at $600{ }^{\circ} \mathrm{C}$ for $1 \mathrm{~h}$. Subsequently, the micro reactor was cooled down to $70{ }^{\circ} \mathrm{C}$ and the sample was saturated in a flow $(20 \mathrm{~mL} /$ min) of gas mixture containing $1 \mathrm{vol} \%$ of $\mathrm{NH}_{3}$ diluted in helium for about $75 \mathrm{~min}$. Then, the sample was purged in a flow of pure helium until a constant baseline level was attained (about $2 \mathrm{~h}$ ). In the next step the temperature of the reactor was raised in the range of $70-600{ }^{\circ} \mathrm{C}$ with a linear heating rate of $10{ }^{\circ} \mathrm{C} / \mathrm{min}$ in a flow of pure helium $\left(\mathrm{NH}_{3}-\right.$ TPD) or in a flow of gas mixture containing $5 \mathrm{vol} \%$ of $\mathrm{O}_{2}$ diluted in helium $\left(\mathrm{NH}_{3}-\mathrm{TPSR}\right)$. The total flow rate in each case was $20 \mathrm{~mL} / \mathrm{min}$.

\subsubsection{SCO Catalytic Tests Performed with Various Space Velocities}

Catalytic tests were preformed using the experimental system described above. Prior to the reaction each sample of the catalyst was outgassed in a flow of pure helium at $600{ }^{\circ} \mathrm{C}$ for $1 \mathrm{~h}$. Experiments were done for various amounts of catalyst $(25,50$, and $100 \mathrm{mg})$ in the range of $100-450{ }^{\circ} \mathrm{C}$. The composition of the gas mixture at the reactor inlet was $\left[\mathrm{NH}_{3}\right]=0.5 \mathrm{vol} \%,\left[\mathrm{O}_{2}\right]=2.5 \mathrm{vol} \%$ and
$[\mathrm{He}]=97 \mathrm{vol} \%$. Total flow rate of the reaction mixture was $40 \mathrm{~mL} / \mathrm{min}$, while space velocities were about 15,400 ; 30,800 ; and $61,600 \mathrm{~h}^{-1}$.

\section{Results and Discussion}

The sample codes as well as their cationic ratios and BET surface areas are presented in Table 1, while the X-ray diffractograms of the dried and calcined hydrotalcites are presented in Fig. 1.

All precursors exhibit the typical crystalline hydrotalcite-like structure belonging to the space group R3 $\mathrm{m}$ [16]. Cell parameters were calculated using a position of 110 reflection: $a=2\left(d_{110}\right)$ and positions of basal reflections: $c=\left[3\left(d_{003}\right)+6\left(d_{006}\right)\right] / 2$. The parameter $a$ corresponds to the cation-cation distance within the brucite-like layer, while the parameter $c$ is related to the thickness of the brucite-like layer and the interlayer distance [16]. Additionally, crystal sizes were calculated from the Scherrer equation $D=0.89 \lambda / \beta \cos \theta$, where $D$ is the crystallite size, $\lambda$ - the X-ray wavelength, $\beta$ - the line broadening and $\theta-$ the Bragg angle. Calculated values were shown in Table 2.

The cell parameter $a$ for the $\mathrm{Mg}_{2} \mathrm{Cu}_{0} \mathrm{Fe}_{1}$ sample is typical for a mixed magnesium-iron layered double hydroxide with $\mathrm{M}^{\mathrm{II}} / \mathrm{M}^{\mathrm{III}}$ ratio close to two [17] and in which trivalent cation positions are occupied by $\mathrm{Fe}^{3+}$. Intermetallic distance increases slightly for the series of the copper-doped hydrotalcite-like samples. The result is due to the bigger radius of $\mathrm{Cu}^{2+}$ cations $(0.069 \mathrm{~nm})$ than $\mathrm{Mg}^{2+}$ $(0.065 \mathrm{~nm})$ and $\mathrm{Fe}^{3+}(0.064 \mathrm{~nm})$ introduced into the layers. However, for $\mathrm{Cu}$-rich phases no further increase of parameter $a$ was observed and in the case of $\mathrm{Mg}_{2} \mathrm{Cu}_{1} \mathrm{Fe}_{1}$ sample small additional reflections were detected, probably corresponding to tenorite, $\mathrm{CuO}$. It is well known that for octahedral coordinated cations such as $\mathrm{Ni}^{2+}$ or $\mathrm{Cu}^{2+}$ a strong Jahn-Teller effect may take place. Distortions caused by incorporation of high amounts of $\mathrm{Cu}$ cations cannot be accommodated by a crystalline lattice. The formation of additional $\mathrm{Cu}$-phases is observed, i.e., $\mathrm{Cu}(\mathrm{OH})_{2}$ which transforms into $\mathrm{CuO}$ upon aging treatment. A similar

Table 1 Composition and BET surface area of calcined hydrotalcites

\begin{tabular}{llll}
\hline $\begin{array}{l}\text { Codes of the } \\
\text { samples before } \\
\text { calcination }\end{array}$ & $\begin{array}{l}\text { Codes of the } \\
\text { calcined samples }\end{array}$ & $\begin{array}{l}\mathrm{Mg} / \mathrm{Cu} / \mathrm{Fe} \\
\text { molar } \\
\text { ratio }\end{array}$ & $\begin{array}{l}\text { BET } \\
\text { surface } \\
\text { area }\left(\mathrm{m}^{2} / \mathrm{g}\right)\end{array}$ \\
\hline $\mathrm{Mg}_{2} \mathrm{Cu}_{1} \mathrm{Fe}_{1}$ & HT-600- $\mathrm{Mg}_{2} \mathrm{Cu}_{1} \mathrm{Fe}_{1}$ & $2 / 1 / 1$ & 43 \\
$\mathrm{Mg}_{2} \mathrm{Cu}_{0.75} \mathrm{Fe}_{1}$ & HT-600- $\mathrm{Mg}_{2} \mathrm{Cu}_{0.75} \mathrm{Fe}_{1}$ & $2 / 0.75 / 1$ & 37 \\
$\mathrm{Mg}_{2} \mathrm{Cu}_{0.5} \mathrm{Fe}_{1}$ & HT-600- $\mathrm{Mg}_{2} \mathrm{Cu}_{0.5} \mathrm{Fe}_{1}$ & $2 / 0.5 / 1$ & 50 \\
$\mathrm{Mg}_{2} \mathrm{Cu}_{0.25} \mathrm{Fe}_{1}$ & HT-600- $\mathrm{Mg}_{2} \mathrm{Cu}_{0.25} \mathrm{Fe}_{1}$ & $2 / 0.25 / 1$ & 54 \\
$\mathrm{Mg}_{2} \mathrm{Cu}_{0} \mathrm{Fe}_{1}$ & HT-600- $\mathrm{Mg}_{2} \mathrm{Cu}_{0} \mathrm{Fe}_{1}$ & $2 / 0 / 1$ & 56 \\
\hline
\end{tabular}



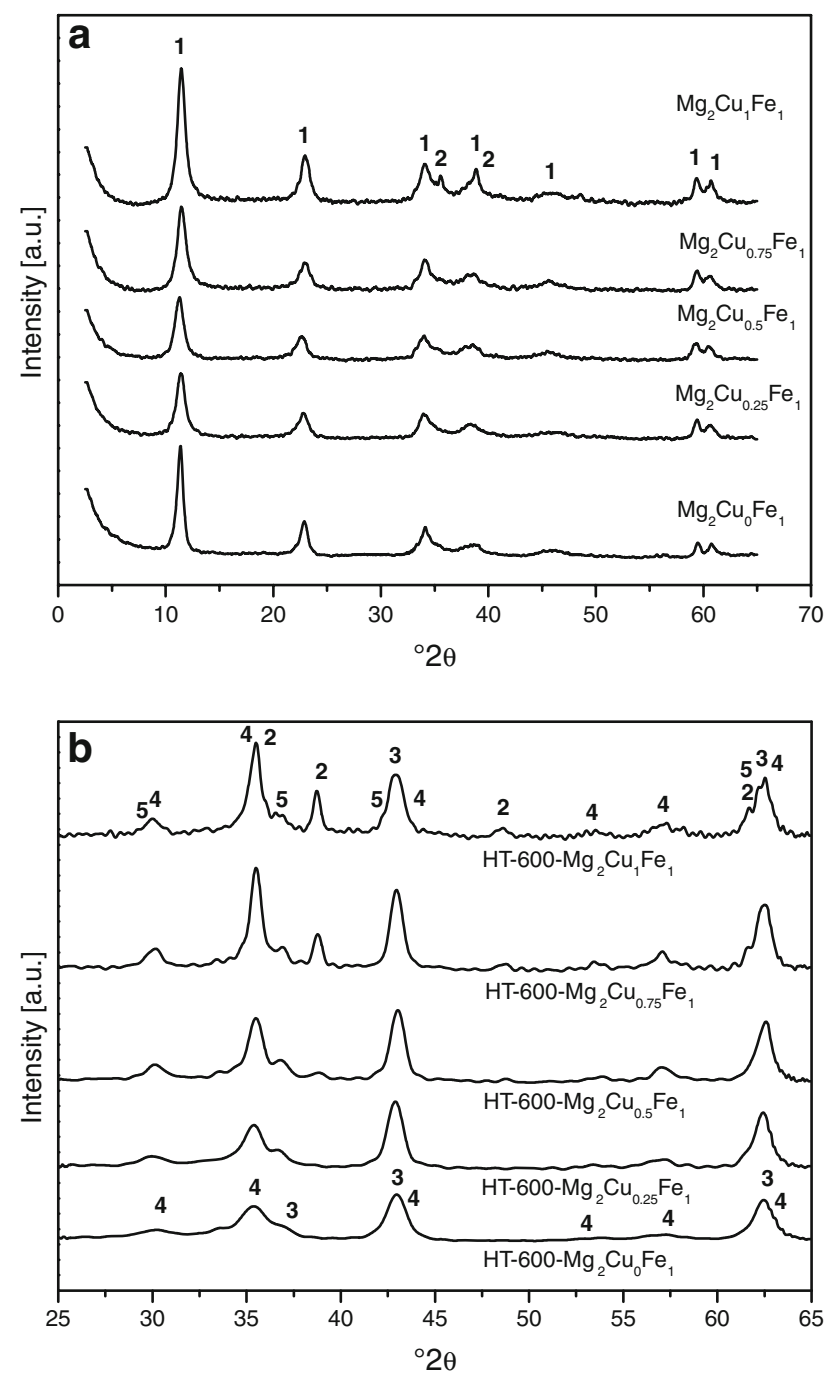

Fig. 1 X-ray diffraction patterns for hydrotalcite-like catalysts' precursors (a) and mixed metal oxide catalysts (b); 1 -hydrotalcite, 2-tenorite, $\mathrm{CuO}, 3$ - periclase, $\mathrm{MgO}$, 4-magnesioferrite, $\mathrm{MgFe}_{2} \mathrm{O}_{4}$, 5 -cuprite, $\mathrm{Cu}_{2} \mathrm{O}$

Table 2 Structural parameters of hydrotalcite-like catalyts' precursors

\begin{tabular}{lllll}
\hline $\begin{array}{l}\text { Codes of the } \\
\text { samples before } \\
\text { calcination }\end{array}$ & $\begin{array}{l}\text { Cell } \\
\text { parameter } \\
a(\mathrm{~nm})\end{array}$ & $\begin{array}{l}\text { Crystallite } \\
\text { size } D a \\
(\mathrm{~nm})\end{array}$ & $\begin{array}{l}\text { Cell } \\
\text { parameter } \\
c(\mathrm{~nm})\end{array}$ & $\begin{array}{l}\text { Crystallite } \\
\text { size } D c \\
(\mathrm{~nm})\end{array}$ \\
\hline $\mathrm{Mg}_{2} \mathrm{Cu}_{1} \mathrm{Fe}_{1}$ & 0.3110 & 28 & 2.318 & 17 \\
$\mathrm{Mg}_{2} \mathrm{Cu}_{0.75} \mathrm{Fe}_{1}$ & 0.3110 & 31 & 2.317 & 15 \\
$\mathrm{Mg}_{2} \mathrm{Cu}_{0.5} \mathrm{Fe}_{1}$ & 0.3115 & 25 & 2.357 & 16 \\
$\mathrm{Mg}_{2} \mathrm{Cu}_{0.25} \mathrm{Fe}_{1}$ & 0.3110 & 33 & 2.333 & 16 \\
$\mathrm{Mg}_{2} \mathrm{Cu}_{0} \mathrm{Fe}_{1}$ & 0.3105 & 35 & 2.335 & 23 \\
\hline
\end{tabular}

effect of $\mathrm{Cu}$ doping was also reported for a $\mathrm{Co}-\mathrm{Cu}-\mathrm{Fe}$ hydrotalcite series [18].

It was reported before that the interlayer distance is also affected by the introduction of copper [18, 19]. Basal spacing depends on the interlayer water content, the amount, size, orientation, and charge of the anion located between the brucite-like layers [17]. The values obtained in the study of about $2.3 \mathrm{~nm}$ are typical for hydrotalcites containing carbonate as the interlayer anion; however, parameter $c$ increases for small $\mathrm{Cu}$-concentrations $\left(\mathrm{Mg}_{2} \mathrm{Cu}_{0.5} \mathrm{Fe}_{1}\right)$. This result can be attributed to a decrease in the electrostatic interactions between the layer and the interlayer network when another divalent cation is introduced into the structure. Further introduction of $\mathrm{Cu}$ results in contraction of basal spacings. Possible phase segregation, as described above, may again cause an increase of the charge density in the layers and a subsequent increase in the attractive electrostatic force. Introduction of $\mathrm{Cu}^{2+}$ and distortions within the hydrotalcite structure resulted in broadening of the reflections in all $\mathrm{Cu}$-doped samples. Consequently, crystallinity of those materials is lower in comparison to $\mathrm{Mg} / \mathrm{Fe}$ hydrotalcite.

The layered structure of the calcined samples was destroyed upon heating. The mixture of oxide and spinel phases was identified in all samples. The calcined $\mathrm{Mg}-\mathrm{Fe}$ hydrotalcite-like sample (HT-600- $\mathrm{Mg}_{2} \mathrm{Cu}_{0} \mathrm{Fe}_{1}$ ) consisted of poor-crystalline periclase $(\mathrm{MgO})$ and magnesioferrite $\left(\mathrm{MgFe}_{2}^{\mathrm{III}} \mathrm{O}_{4}\right)$ [20, 21], however, another spinel phase $\left(\mathrm{Fe}^{\mathrm{II}} \mathrm{Fe}_{2}^{\mathrm{III}} \mathrm{O}_{4}\right)[20,22]$ also cannot be excluded. Incorporation of increasing amounts of $\mathrm{Cu}$ resulted in the formation of at least four different phases in $\mathrm{Mg}-\mathrm{Cu}-\mathrm{Fe}$ oxide catalysts. Also crystallinity increases gradually with $\mathrm{Cu}$-concentration. The reflections at $36.4,42.3,61.3$, and $29.6^{\circ} 2 \theta$ observed in all the $\mathrm{Cu}$-doped catalysts can be attributed to cuprite $\left(\mathrm{Cu}_{2} \mathrm{O}\right)$ [20, 23]. Formation of tenorite $(\mathrm{CuO})$, on the other hand, depends on high copper concentration. Sharp reflections, partially overlapped by the other phases, were observed at $35.6,38.7,48.8$, and $61.6^{\circ} 2 \theta$. This result can be attributed to the temperature-induced reduction which occurs easily for highly dispersed $\mathrm{CuO}$. Besides periclase and magnesioferrite, the presence of other iron oxides is also possible. However, no traces of cuprospinel $\left(\mathrm{Cu}^{\mathrm{II}}, \mathrm{Mg}\right) \mathrm{Fe}_{2}^{\mathrm{III}} \mathrm{O}_{4}$ or $\mathrm{Cu}^{\mathrm{II}} \mathrm{Fe}_{2}^{\mathrm{III}} \mathrm{O}_{4}$ were found [24].

TPRed profiles of the calcined hydrotalcite samples are presented in Fig. 2. Sharp peaks at about $190-195^{\circ} \mathrm{C}$ and 200-205 (marked in Fig. 2 as $\alpha$ and $\beta$ ) were found for the copper containing samples. The $\alpha$ peak is related to the reduction of highly dispersed copper oxide species, which include isolated copper ions and small two- and threedimensional clusters [25-28]. The $\beta$ peak is associated with reduction of bulk-like $\mathrm{CuO}$ phases that include large clusters and bulk $\mathrm{CuO}$. Therefore, it is not surprising that the intensity of the $\beta$ peak increased with an increase in the copper content. The TPRed peaks related to reduction of iron species appeared at temperatures $460-480{ }^{\circ} \mathrm{C}$ (peak $\gamma$ ) and $540-620^{\circ} \mathrm{C}$ (peak $\delta$ ). XRD studies have shown that iron could be present in the form of $\mathrm{MgFe}_{2}^{\mathrm{III}} \mathrm{O}_{4}$ and/or 


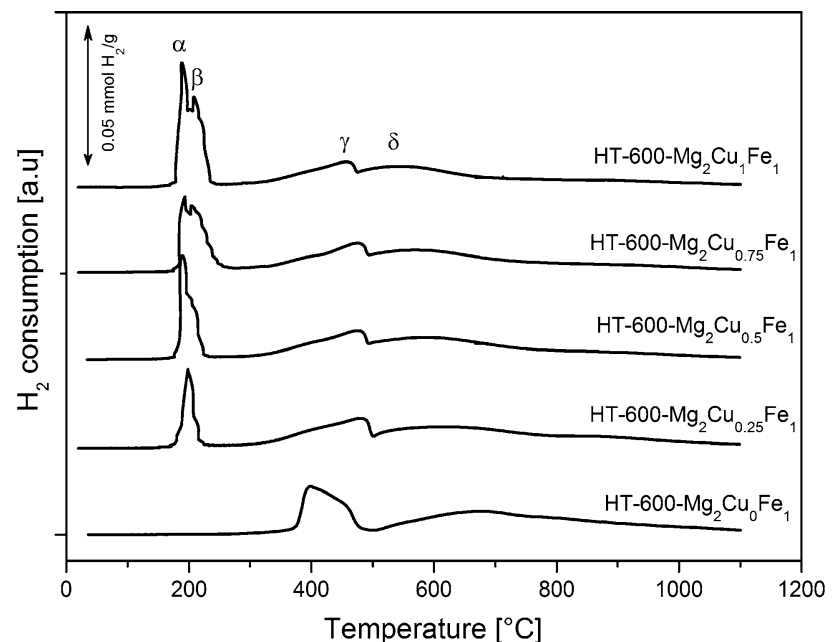

Fig. 2 Temperature-programmed reduction (TPRed) of mixed metal oxide catalysts. Conditions: $30 \mathrm{mg}$ catalyst, $10 \% \mathrm{H}_{2}$ diluted in $\mathrm{Ar}$, flow rate of $6 \mathrm{~mL} / \mathrm{min}$, linear heating rate of $5{ }^{\circ} \mathrm{C} / \mathrm{min}$

$\mathrm{Fe}^{\mathrm{II}} \mathrm{Fe}_{2}^{\mathrm{III}} \mathrm{O}_{4}$, however, distinction between these two spinel oxides was not possible by the XRD method due to very similar diffraction patterns. More information concerning the contribution of both these spinel phases in the catalysts can be obtained from TPRed experiments. Assuming that both spinel oxides are reduced by hydrogen in two steps $[28,29]$ the processes could be presented in the form of the following equations:

$\mathrm{MgFe}_{2}^{\mathrm{III}} \mathrm{O}_{4} \rightarrow \mathrm{MgO}+2 \mathrm{FeO} \rightarrow \mathrm{MgO}+2 \mathrm{Fe}$

$\mathrm{Fe}^{\mathrm{II}} \mathrm{Fe}_{2}^{\mathrm{III}} \mathrm{O}_{4} \rightarrow 3 \mathrm{FeO} \rightarrow 3 \mathrm{Fe}$

Therefore for the reduction of iron in $\mathrm{MgFe}_{2}^{\mathrm{III}} \mathrm{O}_{4}$ the ratio of hydrogen consumption in the first and second step is 1:2, while for the reduction of $\mathrm{Fe}^{\mathrm{II}} \mathrm{Fe}_{2}^{\mathrm{III}} \mathrm{O}_{4}$ it is $1: 3$. Analysis of the TPRed results showed that the hydrogen consumption ratio for both steps was 1:2.12 and 1:2.14 for the samples with the lower $\mathrm{Cu}$-content (HT-600- $\mathrm{Mg}_{2} \mathrm{Cu}_{0.25} \mathrm{Fe}_{1}$ and HT-600- $\mathrm{Mg}_{2} \mathrm{Cu}_{0.5} \mathrm{Fe}_{1}$, respectively) and 1:2.64 and 1:2.27 for the samples with the higher Cu-content (HT-600$\mathrm{Mg}_{2} \mathrm{Cu}_{0.75} \mathrm{Fe}_{1}$ and HT-600- $\mathrm{Mg}_{2} \mathrm{Cu}_{1} \mathrm{Fe}_{1}$, respectively), while the ratio of 1:2.42 was found for the sample without copper (HT-600- $\mathrm{Mg}_{2} \mathrm{Cu}_{0} \mathrm{Fe}_{1}$ ) Therefore, it could be concluded that both spinel phases are present in the samples but their contribution is varied.

Calcined hydrotalcites were tested as catalysts for the selective oxidation of ammonia. Nitrogen and water vapour are desired products of this process, while nitrogen oxides are undesired by-products. Results of activity studies are presented in Fig. 3. Oxidation of ammonia started at $225-250{ }^{\circ} \mathrm{C}$, while temperatures $425-450{ }^{\circ} \mathrm{C}$ were necessary for the complete ammonia conversion in the reaction mixture. An exception was the catalyst without copper (HT-600- $\mathrm{Mg}_{2} \mathrm{Cu}_{0} \mathrm{Fe}_{1}$ ), which was found to be significantly
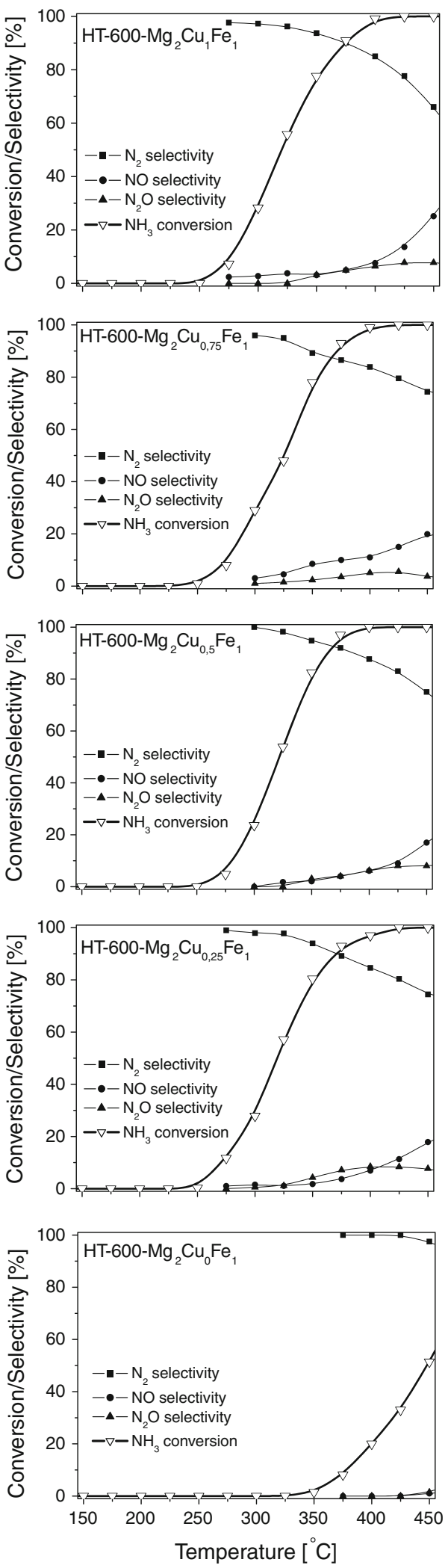

Fig. 3 Selective catalytic oxidation of ammonia over hydrotalcite derived catalysts. Conditions: $100 \mathrm{mg}$ catalyst, $\left[\mathrm{NH}_{3}\right]=0.5 \%$, $\left[\mathrm{O}_{2}\right]=2.5 \%,[\mathrm{He}]=97 \%$, total flow rate $=40 \mathrm{~mL} / \mathrm{min}$ 
less active. For this catalyst, ammonia oxidation started at $325{ }^{\circ} \mathrm{C}$ and its complete removal from the reaction mixture was not obtained in the studied temperature range. Therefore, it could be concluded that the presence of copper activated catalysts for the low-temperature ammonia oxidation is essential. On the other hand, the copper content in the samples only slightly differentiated their catalytic activity. $\mathrm{N}_{2}, \mathrm{NO}$, and $\mathrm{N}_{2} \mathrm{O}$ were the only detected $\mathrm{N}$-containing reaction products. For all the catalysts, nitrogen was the dominating product in the studied temperature range; however, its concentration decreased with rising reaction temperature. An opposite effect was observed for the evolution of NO. Selectivity to $\mathrm{N}_{2} \mathrm{O}$ was rather low and did not exceed $12 \%$ in the studied temperature range. Catalysts composition strongly influenced their selectivity to $\mathrm{N}$-containing products. For the catalysts with the highest $\mathrm{Cu}$-loading (HT-600- $\mathrm{Mg}_{2} \mathrm{Cu}_{1} \mathrm{Fe}_{1}$ ) an increase in $\mathrm{NO}$ selectivity and decrease in $\mathrm{N}_{2}$ selectivity at higher temperatures was more significant in comparison to the other $\mathrm{Cu}$-containing samples. Taking into account both high activity and selectivity to nitrogen the best results were presented by the HT-600- $\mathrm{Mg}_{2} \mathrm{Cu}_{0.5} \mathrm{Fe}_{1}$ catalyst, which was able to completely oxidise ammonia in the reaction mixture at $400{ }^{\circ} \mathrm{C}$ with a selectivity to nitrogen of about $88 \%$.

For the HT-600- $\mathrm{Mg}_{2} \mathrm{Cu}_{0.5} \mathrm{Fe}_{1}$ catalyst additional catalytic tests with a gas mixture containing water vapour were done (Fig. 4). The temperature of complete ammonia conversion increased by about $25^{\circ} \mathrm{C}$ after the introduction of water vapour into the reaction mixture (Fig. 4a). Also an increase in $\mathrm{NO}$ selectivity and decrease in $\mathrm{N}_{2}$ selectivity was observed for the process performed in the presence of wet reaction mixture. Figure $4 \mathrm{~b}$ presents stability tests performed for the HT-600- $\mathrm{Mg}_{2} \mathrm{Cu}_{0.5} \mathrm{Fe}_{1}$ catalyst in a flow of dry and wet reaction mixture. The introduction of water vapour into the reaction mixture only slightly decreased ammonia conversion and selectivity to nitrogen. However, switching from wet to dry reaction mixture resulted in an increase of these parameters to the former level. Therefore, it could be concluded that introduction of water vapour into the reaction mixture did not result in the permanent deactivation of the catalyst. It should be also noted that any significant depletion in conversion and selectivity was not observed within the period of prolonged activity tests with wet nor dry reaction mixture (Fig. 4b). Comparing the obtained results with that reported in the scientific literature it could be concluded the studied catalyst is significantly less sensitive to the presence of water vapour than other active $\mathrm{Cu}$-doped catalysts of the SCO process (e.g., $\mathrm{Cu} / \mathrm{TiO}_{2}$ [8], $\left.\mathrm{Cu} / \mathrm{Al}_{2} \mathrm{O}_{3}, \mathrm{CuY}[9,10]\right)$.

The interaction of ammonia molecules with the catalysts' surface was studied by temperature-programmed methods. The results of temperature-programmed desorption of ammonia $\left(\mathrm{NH}_{3}-\mathrm{TPD}\right)$ are shown in Fig. 5. For all the samples, apart from ammonia desorption, also the evolution of $\mathrm{N}_{2}$ and $\mathrm{N}_{2} \mathrm{O}$ was detected. Nitrogen was formed at temperatures below $400{ }^{\circ} \mathrm{C}$ and its evolution is represented by desorption curves with different shapes. For HT-600- $\mathrm{Mg}_{2} \mathrm{Cu}_{0.5} \mathrm{Fe}_{1}$ the evolution of nitrogen proceeded in one stage, while in the case of the other catalysts at least two peaks of nitrogen evolution were detected. For the $\mathrm{Cu}$-containing catalysts the evolution of $\mathrm{N}_{2} \mathrm{O}$ was observed in the temperature range of $150-400{ }^{\circ} \mathrm{C}$, while the formation of nitrous oxide over HT-600- $\mathrm{Mg}_{2} \mathrm{Cu}_{0} \mathrm{Fe}_{1}$ was detected at higher temperatures and proceeded in two stages $260-375^{\circ} \mathrm{C}$ and $415-510{ }^{\circ} \mathrm{C}$. This effect is probably related to the presence of strongly chemisorbed ammonia on the surface of the HT-600- $\mathrm{Mg}_{2} \mathrm{Cu}_{0} \mathrm{Fe}_{1}$ sample.

The evolution of $\mathrm{N}_{2}$ and $\mathrm{N}_{2} \mathrm{O}$ that assisted ammonia desorption is related to the partial oxidation of ammonia by lattice oxygen of the catalysts. Therefore, lattice oxygen seems to be able to directly oxidize ammonia.

Figure 6 presents the results of $\mathrm{NH}_{3}$-TPSR measurements. Apart from ammonia, evolution of $\mathrm{N}_{2}, \mathrm{~N}_{2} \mathrm{O}$, and NO was also detected. A significant amount of desorbed ammonia suggests that the majority of chemisorbed $\mathrm{NH}_{3}$ molecules are not involved in the low-temperature oxidation. The evolution of nitrogen and nitrous oxide for all the copper containing catalysts occurred at temperatures below
Fig. 4 Selective catalytic oxidation of ammonia over HT- $600-\mathrm{Mg}_{2} \mathrm{Cu}_{0.5} \mathrm{Fe}_{1}$ catalyst. Conditions: $100 \mathrm{mg}$ catalyst, $\left[\mathrm{NH}_{3}\right]=0.5 \%,\left[\mathrm{O}_{2}\right]=2.5 \%$, $\left(\left[\mathrm{H}_{2} \mathrm{O}\right]=3.4 \%\right)$, $\mathrm{He}=$ balance, total flow rate $=40 \mathrm{~mL} / \mathrm{min}$. a Studies performed in polythermal conditions in flow of dry (empty symbols) and wet (full symbols) reaction mixture; b Studies performed at $400{ }^{\circ} \mathrm{C}$ with wet and dry reaction mixture
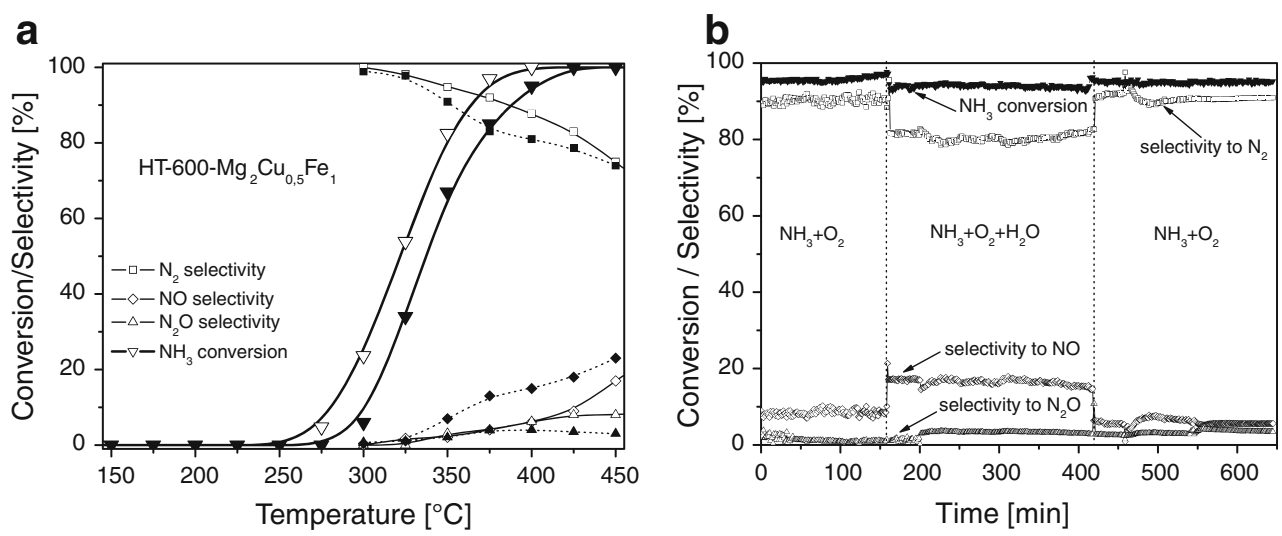

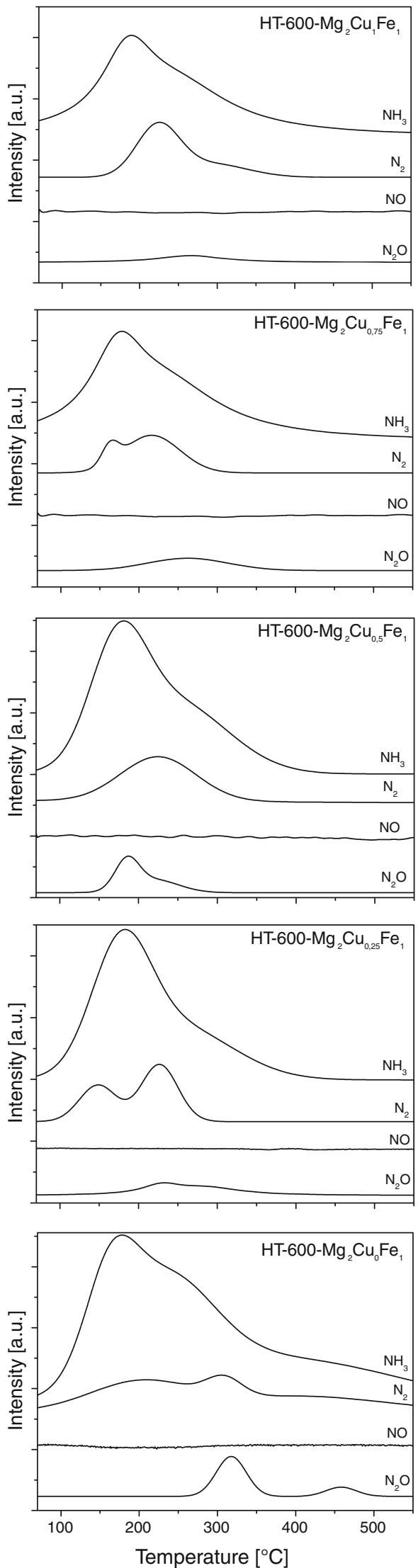

Fig. 5 Results of temperature-programmed desorption of $\mathrm{NH}_{3}\left(\mathrm{NH}_{3}-\right.$ TPD) obtained for hydrotalcite derived catalysts. Conditions: $100 \mathrm{mg}$ catalyst, adsorption: $70{ }^{\circ} \mathrm{C}, 1 \% \mathrm{NH}_{3}$ diluted in $\mathrm{He}$, flow rate $=$ $20 \mathrm{~mL} / \mathrm{min}$, desorption: flow of pure $\mathrm{He}=20 \mathrm{~mL} / \mathrm{min}$, linear heating rate of $10^{\circ} \mathrm{C} / \mathrm{min}$

$400{ }^{\circ} \mathrm{C}$. The evolution of $\mathrm{N}_{2} \mathrm{O}$ from the HT-600$\mathrm{Mg}_{2} \mathrm{Cu}_{0} \mathrm{Fe}_{1}$ sample, similarly to $\mathrm{NH}_{3}-\mathrm{TPD}$, was detected at higher temperatures and proceeded in two, well resolved stages. The evolution of $\mathrm{NO}$ was the main difference between the results of $\mathrm{NH}_{3}-\mathrm{TPD}$ and $\mathrm{NH}_{3}-\mathrm{TPSR}$. Nitric oxide was produced for all the samples in the temperature range of $350-500{ }^{\circ} \mathrm{C}$.

Three major reaction mechanisms have been proposed for the SCO process over various types of catalysts. The first mechanism, which is often called the imide mechanism, was proposed by Zawadzki [30]. In the first step ammonia is oxidized with the formation of imide $(\mathrm{NH})$, then the imide species react with molecular oxygen $(\mathrm{O})$ to form the nitrosyl (HNO) intermediate, which in the next step reacts with imide resulting in the formation of $\mathrm{N}_{2}$ and $\mathrm{H}_{2} \mathrm{O} . \mathrm{N}_{2} \mathrm{O}$ is formed by the reaction of two nitrosyl species, while the reaction between $\mathrm{NH}$ and $\mathrm{O}_{2}$ leads to $\mathrm{NO}$. According to this mechanism, dissociation of $\mathrm{O}_{2}$ and formation of active atomic oxygen species $(\mathrm{O})$ is the key reaction step.

On the other hand, in our studies the oxidation of ammonia into $\mathrm{N}_{2}$ and $\mathrm{N}_{2} \mathrm{O}$ took place at a similar temperature range in the presence $\left(\mathrm{NH}_{3}-\mathrm{TPSR}\right)$ or absence $\left(\mathrm{NH}_{3}-\mathrm{TPD}\right)$ of gaseous oxygen $\left(\mathrm{O}_{2}\right)$. Therefore, it seems that the formation of active atomic oxygen species $(\mathrm{O})$ by dissociation of $\mathrm{O}_{2}$ did not occur over the studied catalysts and the evolution of $\mathrm{N}_{2}$ and $\mathrm{N}_{2} \mathrm{O}$ involved the reaction of ammonia with the lattice oxygen.

The second mechanism, called the hydrazine mechanism (e.g., [31, 32]), involves oxidation of ammonia to amide $\left(\mathrm{NH}_{2}\right)$ species by atomic oxygen $(\mathrm{O})$, and subsequently the formation of hydrazine-type intermediates $\left(\mathrm{N}_{2} \mathrm{H}_{4}\right)$. In the next step $\mathrm{N}_{2} \mathrm{H}_{4}$ is oxidised by $\mathrm{O}_{2}$ to $\mathrm{N}_{2}$ and/ or $\mathrm{N}_{2} \mathrm{O}$. It should be noted that also in this case active oxygen species play an important role in the reaction mechanism.

The third mechanism, also called "internal" selective catalytic reduction (iSCR) (e.g., [13, 33, 34]) consists of two main steps. In the first step ammonia is oxidised to NO:

$4 \mathrm{NH}_{3}+5 \mathrm{O}_{2} \rightarrow 4 \mathrm{NO}+6 \mathrm{H}_{2} \mathrm{O}$

While, $\mathrm{N}_{2}$ and $\mathrm{N}_{2} \mathrm{O}$ are formed in the subsequent reactions between $\mathrm{NO}$ and ammonia, which were not consumed in the process 1 :

$4 \mathrm{NO}+4 \mathrm{NH}_{3}+\mathrm{O}_{2} \rightarrow 4 \mathrm{~N}_{2}+6 \mathrm{H}_{2} \mathrm{O}$ 

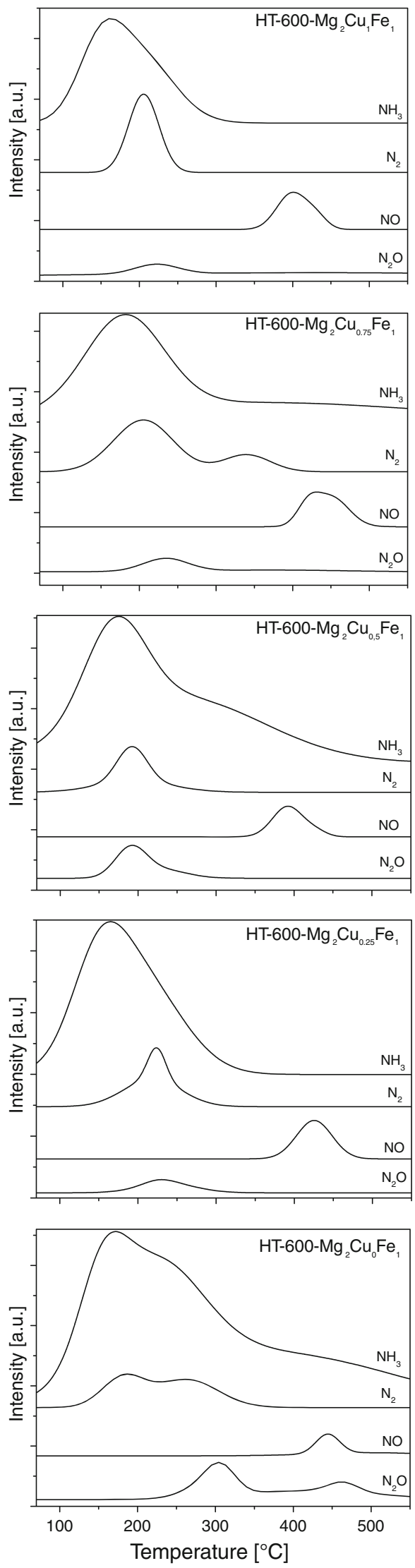

Fig. 6 Results of temperature-programmed surface reaction $\left(\mathrm{NH}_{3}-\right.$ TPSR) obtained for hydrotalcite derived catalysts. Conditions: $100 \mathrm{mg}$ catalyst, adsorption: $70{ }^{\circ} \mathrm{C}, 1 \% \mathrm{NH}_{3}$ diluted in $\mathrm{He}$, flow rate $=20 \mathrm{~mL} / \mathrm{min}$, desorption: $5 \% \mathrm{O}_{2}$ diluted in $\mathrm{He}$, flow rate $=20 \mathrm{~mL} /$ min, linear heating rate of $10{ }^{\circ} \mathrm{C} / \mathrm{min}$

$4 \mathrm{NO}+4 \mathrm{NH}_{3}+3 \mathrm{O}_{2} \rightarrow 4 \mathrm{~N}_{2} \mathrm{O}+6 \mathrm{H}_{2} \mathrm{O}$

If the process of ammonia oxidation proceeds according to the iSCR mechanism, the studied catalysts should also be active in the selective catalytic reduction of NO with ammonia (NO-SCR). Results of the studies of NO-SCR reaction are presented in Fig. 7. All the $\mathrm{Cu}$-containing samples were catalytically active in the low-temperature range, however, at temperatures above $300{ }^{\circ} \mathrm{C}$ intensive ammonia oxidation drastically decreased the effectiveness of NO reduction. The HT- $600-\mathrm{Mg}_{2} \mathrm{Cu}_{0} \mathrm{Fe}_{1}$ catalyst (without copper) was active at temperatures above $350{ }^{\circ} \mathrm{C}$. It should be noted that ammonia oxidation in the SCO process over the copper containing catalysts started at about $225^{\circ} \mathrm{C}$ (Fig. 2), while conversion of NO on the NO-SCR process
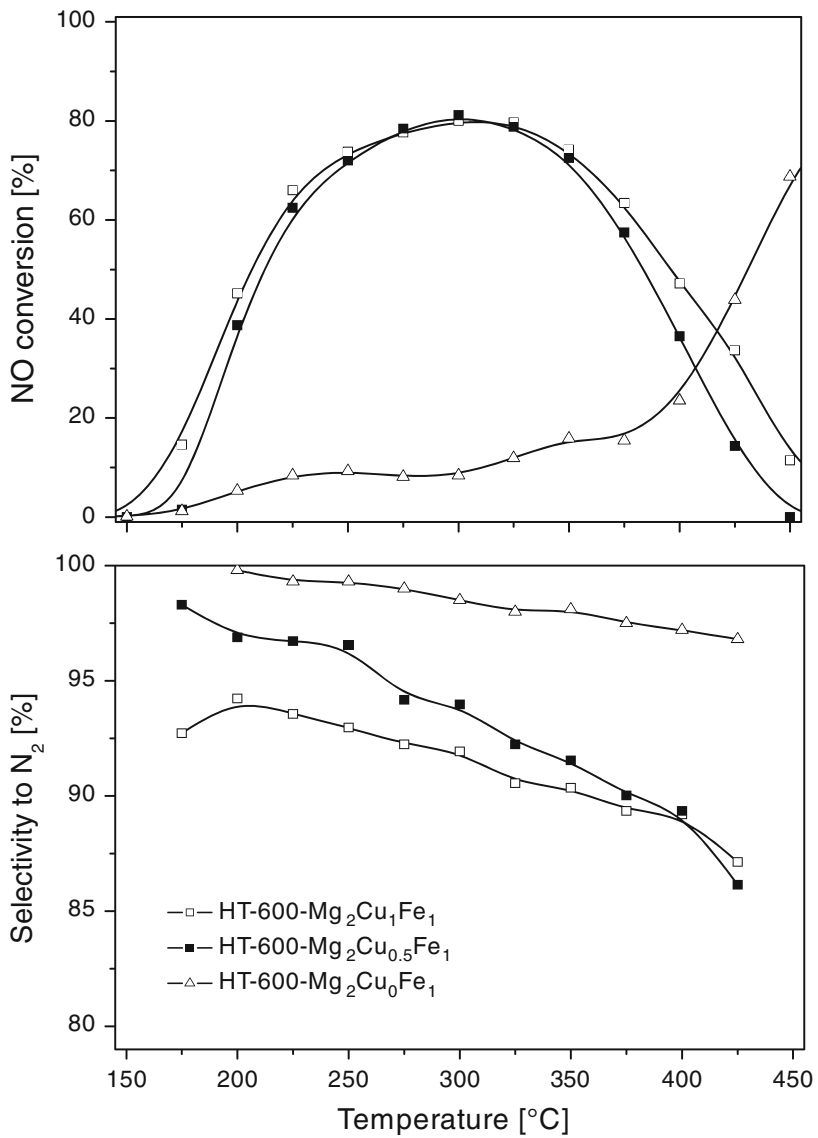

Fig. 7 Selective catalytic reduction of NO with ammonia over hydrotalcite derived catalysts. Conditions: $100 \mathrm{mg}$ catalyst, $\left[\mathrm{NH}_{3}\right]=0.25 \%,[\mathrm{NO}]=0.25 \%,\left[\mathrm{O}_{2}\right]=2.5 \%,[\mathrm{He}]=97 \%$, total flow rate $=40 \mathrm{~mL} / \mathrm{min}$ 

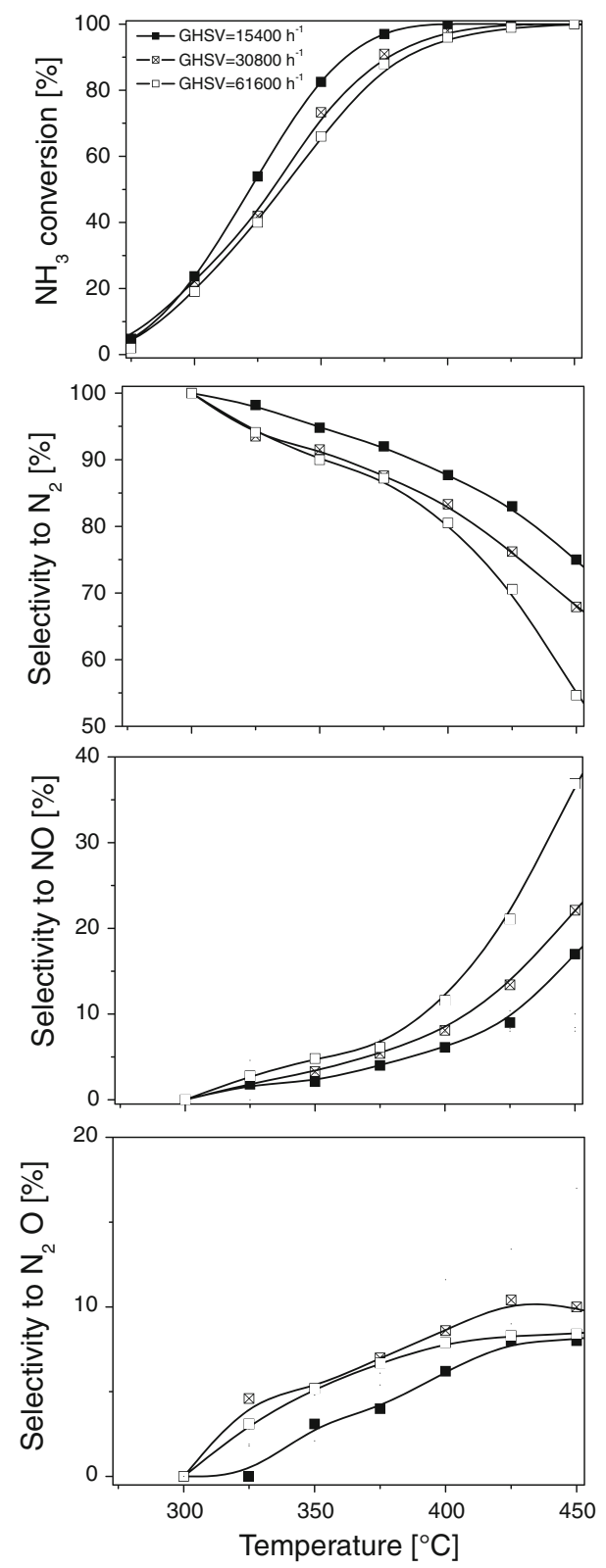

Fig. 8 Effect of space velocity (SV) on activity and selectivity of HT- $600-\mathrm{Mg}_{2} \mathrm{Cu}_{0.5} \mathrm{Fe}_{1}$ catalyst in the SCO process. Conditions: 25,50 or $100 \mathrm{mg}$ catalyst, $\left[\mathrm{NH}_{3}\right]=0.5 \%,\left[\mathrm{O}_{2}\right]=2.5 \%, \mathrm{He}=$ balance, total flow rate $=40 \mathrm{~mL} / \mathrm{min}$

(Fig. 7) was observed at temperatures lower by about $75^{\circ} \mathrm{C}$. If we assume the iSCR mechanism of the SCO process is correct, it seems that oxidation of ammonia into NO (reaction 1) is a rate-determining step in the lowtemperature range.

If the process of ammonia oxidation proceeds according to the sequence of the reactions presented above (iSCR mechanism) the distribution of products should depend on the space velocity (SV) of the process. For the experiment performed with lower SV (longer contact time) the increased selectivity to $\mathrm{N}_{2}$ and $\mathrm{N}_{2} \mathrm{O}$ is expected, while an increase in SV (shorter contact time) should promote the higher selectivity to NO. Figure 8 presents the results of the catalytic tests performed for the various space velocities. An increase in SV shifted the ammonia conversion curves into higher temperatures as well as decreased selectivity to nitrogen and increased selectivity to nitric oxide. Selectivity to nitrous oxide was rather low and only slightly affected by the changes in space velocity. The obtained results prove that the process of ammonia oxidation proceeds according to the sequence of the reactions $1,2 \mathrm{a}$, or $2 \mathrm{~b}$. This hypothesis is also supported by the results of $\mathrm{NH}_{3}$-TPSR experiments. The evolution of $\mathrm{NO}$ was observed only in the high temperature range (Fig. 6), in which there was no chemisorbed ammonia able to convert nitric oxide to $\mathrm{N}_{2}$ or $\mathrm{N}_{2} \mathrm{O}$.

\section{Conclusions}

Calcined $\mathrm{Mg}-\mathrm{Cu}-\mathrm{Fe}$ hydrotalcites were found to be active catalysts for the selective oxidation of ammonia. Activity of these catalysts depended on their chemical composition. The $\mathrm{Cu}$-containing catalysts were active at lower temperatures and were less selective to nitrogen than the sample without copper (HT-600- $\mathrm{Mg}_{2} \mathrm{Cu}_{0} \mathrm{Fe}_{1}$ ). Optimum composition of the catalysts guaranteeing high activity and selectivity to $\mathrm{N}_{2}$ was proposed. The studies of the reaction mechanism showed that the process of ammonia oxidation over the hydrotalcite derived catalysts proceeds according to the internal selective catalytic reduction mechanism (iSCR).

Acknowledgments Authors are grateful to Krzysztof Kiper and Tony Robinson for proofreading of the manuscript.

Open Access This article is distributed under the terms of the Creative Commons Attribution Noncommercial License which permits any noncommercial use, distribution, and reproduction in any medium, provided the original author(s) and source are credited.

\section{References}

1. Olofsson G, Hinz A, Anderson A (2004) Chem Eng Sci 59:4113

2. Li Y, Armor JN (1997) Appl Catal B 13:131

3. Amblard M, Burch R, Southward BWL (1999) Appl Catal B 22: L159

4. Sobczyk PD, Hensen EJM, de Jong AM, van Santen AS (2003) Top Catal 23:109

5. Long RQ, Yang RT (2002) Catal Lett 78:353

6. Cui X, Zou J, Ye Z, Chen H, Li L, Ruan M, Shi J (2010) J Catal 270:310

7. Lenihan S, Curtin T (2009) Catal Today 145:85

8. He S, Zhang C, Yang M, Zhang Y, Xu W, Cao N, He H (2007) Sep Purif Technol 58:173

9. Gang L, Grondelle J, Anderson BG, Santen RA (1999) J Catal 186: 100 
10. Gang L, Anderson BG, Grondelle J, Santen RA (2000) Catal Today 61:179

11. Hung C-M (2009) Powder Technol 196:56

12. Chmielarz L, Kuśtrowski P, Drozdek M, Dziembaj R, Cool P, Vansant EF (2007) Catal Today 119:181

13. Chmielarz L, Kuśtrowski P, Rafalska-Łasocha A, Dziembaj R (2005) Appl Catal B 58:235

14. Chmielarz L, Kuśtrowski P, Rafalska-Łasocha A, Majda D, Dziembaj R (2002) Appl Catal B 35:195

15. Chmielarz L, Kuśtrowski P, Rafalska-Łasocha A, Dziembaj R (2003) Thermochim Acta 395:225

16. Wegrzyn A, Rafalska-Łasocha A, Majda D, Dziembaj R, Papp H (2010) J Therm Anal Calorim 99:443

17. Sanchez-Cantu M, Perez-Diaz LM, Maubert AM, Valente JS (2010) Catal Today 150:332

18. Iglesias AH, Ferreira OP, Gouveia DX, Souza Filio AG, de Paiva Mendel JAC, Filio J, Alves OL (2005) J Solid State Chem 178: 142

19. Carja G, Nakamura R, Niiyama H (2002) Appl Catal A 236:91

20. Downs RT (2006) The RRUFF project: an integrated study of the chemistry, crystallography, Raman and infrared spectroscopy of minerals. In: Program and abstracts of the 19th general meeting of the international mineralogical association in Kobe, Japan. O03-13
21. O’Neill HSC, Annersten H, Virgo D (1992) Am Miner 77:725

22. Blesa MC, Amador U, Moran E, Menendez N, Tornero JD, Rodriguez-Carvajal J (1993) Solid State Ion 63:429

23. Hafner SS, Nagel S (1983) Phys Chem Miner 9:19

24. Estrella M, Barrio L, Zhou G, Wang X, Wang Q, Wen W, Hanson JC, Frenkel AI, Rodriguez JA (2009) J Phys Chem C 113: 14411

25. Kim S-K, Kim K-H, Ihm S-K (2007) Chemosphere 68:287

26. Chary KVR, Seela KK, Ramakanth DNP (2008) Catal Commun 9:75

27. Dow W-P, Wang Y-P, Huang T-J (2000) Appl Catal A 190:25

28. Balasamy RJ, Khurshid A, Al-Ali AAS, Atanda LA, Legata K, Asamoto M, Yahiro H, Nomura K, Sano T, Takehira K, Al-Khattaf SS (2010) Appl Catal A 390:225

29. Holgado MJ, Rivers V, Sanroman MS, Malet P (1996) Solid State Ion 92:273

30. Zawadzki J (1950) Disc Faraday Soc 8:140

31. Amores JMG, Escribano VS, Ramis G, Busca G (1997) Appl Catal B 13:45

32. Darvell LI, Heiskanen K, Jones JM, Ross AB, Simell P, Williams A (2003) Catal Today 81:681

33. Qi G, Gatt JE, Yang RT (2004) J Catal 226:120

34. Zhang L, He H (2009) J Catal 268:18 